Volume 2 Nomor 1, Januari-Juni 2018: hlm. 33-42. Magister Ilmu Hukum, Fakultas Hukum, Universitas Lampung, Bandar Lampung, Lampung, Indonesia.

E-ISSN: 2598-3105 P-ISSN: 2723-2581

http://jurnal.fh.unila.ac.id/index.php/cepalo

\title{
TANGGUNG JAWAB HUKUM DOKTER TERHADAP KESALAHAN DIAGNOSIS PENYAKIT KEPADA PASIEN
}

\section{DOCTOR'S LEGAL RESPONSIBILITY FOR MISDIAGNOSIS OF DISEASE TO PATIENTS}

\author{
Dian Mauli \\ Rumah Sakit Umum Daerah Dr.H. Abdul Moeloek \\ monalisamauli@yahoo.com
}

\begin{abstract}
Abstrak
Terjadinya ikatan antara pasien dan dokternya bermula ketika pasien meminta bantuan dokter mengenai kesehatannya. Hubungan demikian dikenal dengan kontrak teraupetik. Tidak dapat disangkal bahwa selalu akan terjadi sengketa antara dokter dan pasiennya. Dalam penelitian ini ditemukan beberapa masalah diantaranya, yang pertama mengenai indikatorindikator yang berimbas pada terjadinya kesalahan diagnosis oleh dokter, lalu yang kedua adalah dasar hukum penuntutan terhadap dokter jika kesalahan diagnosis terjadi. Dan dengan itu didapat hasil penelitian sebagai berikut: yang pertama, ditemukan prosedur penegakan diagnosis yaitu; anamnesis, pemeriksaaan fisik, pemeriksaan penunjang dan diagnosis, selain itu ditemukan indikator yang berimbas pada terjadinya kesalahan diagnosis seperti, kurangnya kuantitas tenaga medis pada tempat-tempat pelayanan kesehatan serta tidak lengkapnya fasilitas pemeriksaan penunjang. Menurut data yang diambil dari salah satu Puskesmas di Lampung Utara tercatat, bahkan tidak memiliki dokter dan fasilitas lain, hal ini tentu bertentangan dengan Peraturan Menteri Kesehatan No. 75 Tahun 2014, yang menyebutkan bahwa setiap Puskesmas harus memiliki minimal 2 dokter. Temuan yang kedua, adalah bahwa dokter yang melakukan kesalahan diagnosis harus bertanggung jawab berdasarkan Kode Etik Kedokteran Indonesia (KODEKI) dan Undang-Undang Nomor 29 Tahun 2004 Tentang Praktek Kedokteran. Tanggung jawab dokter ini berupa tanggung jawab etis dan tanggung jawab disiplin.
\end{abstract}

Kata Kunci: Kesalahan, Diagnosis, Tanggung Jawab.

\begin{abstract}
The bond between the patient and the doctor starts when the patient asks the doctor for help regarding his health. This relationship is known as a therapeutic contract. There is no denying that there will always be disputes between doctors and patients. In this study found several problems including, first about the indicators that impact on the occurrence of misdiagnosis by doctors, then the second is the legal basis for prosecution of doctors if a misdiagnosis occurs. And with that the results of the study are as follows: first, the diagnosis is found; history taking, physical examination, supporting examination and diagnosis, in addition it was found indicators that impacted the occurrence of misdiagnosis such as, lack of quantity of medical personnel in health service places and incomplete supporting examination facilities. According to data taken from one of the Puskesmas in North Lampung, it does not even have a doctor and other facilities, this is certainly contrary to Minister of Health Regulation No. 75 of 2014, which states that each Puskesmas must have at least 2 doctors. The second finding, is that doctors who make misdiagnoses must be held responsible based on the Indonesian Medical Ethics Code (KODEKI) and Law Number 29 Year 2004 Regarding Medical Practices. This doctor's responsibility is in the form of ethical responsibilities and disciplinary responsibilities.

Keywords: Error, Diagnosis, Responsibility.
\end{abstract}


Cara Mengutip (How to Cite): Dian Mauli, "Tanggung Jawab Hukum Dokter Terhadap Kesalahan Diagnosis Penyakit Kepada Pasien”, Jurnal Cepalo, 2 (1), (2018): 33-42.

DOI: https://doi.org/10.25041/cepalo.v2no1.1760

\section{A. Pendahuluan}

Seorang dokter mempunyai tanggung jawab profesi dan etika yang dilahirkan dari hubungan-hubungan antara pasien dan dokter dalam bidang kesehatan, hubungan ini dibagi dua jenis, yaitu hubungan ikatan terapeutik dan hubungan yang ada akibat peraturan undangundang mengatur hal tersebut. Ikatan/hubungan ini kemudian menghasilkan suatu bentuk tanggung jawab seorang dokter yang berupa tanggung jawab secara proesi dan eti.ka. Jika dokter melakukan tindakan-tindakan melawan hukum, maka dapat dilakukan penuntutan hukum untuknya baik di bidang peradilan perdata, peradilan pidana maupun peradilan administratif. Sedangkan apabila dokter melakukan pelanggaran kode etik maka dokter tersebut harus dituntut secara hukum pada Pengadilan Etik yang diselenggarakan oleh Majelis Kehormatan Etika Kedokteran dan Pengadilan Displin yang diselenggarakan oleh Majelis Kehormatan Disiplin Kedokteran Indonesia Maka dari itu, seorang dokter harus bekerja dibawah peraturan perundang- undangan dan standar profesi yang telah ditentukan termasuk Kode etik yang harus mereka patuhi. Ini merupakan hal yang sangat krusial, hal ini disebabkan karena dalam sengketa mengenai pelayanan kesehatan oleh dokter, maka perlu diperhatikam apakah dokter tersebut telah bekerja sesuai aturan atau tidak, jika terbukti terjadi ketidaksesuaian yang menyebabkan terjadi kesalahan diagnosis, maka seorang dokter dapat dinyatakan melakukan melpraktek.

Kesalahan diagnosis ini adalah termasuk dalam kelalaian tindakan medis. Seorang yang lalai adalah mereka yang bertindak tidak peduli dan tidak memperhatikan tindakannya yang berakibat kerugian atau cedera kepada oramg lain, namun jika kelalaian itu adalah hal-hal yang masih dianggap ringan/ tidak merugikan secara berat, maka kelalaian tersebut tidak berakibat hukum apapun (De minisis not curat lex principle). Tetapi, jika kelalaian tersebut mengakibatkan kerugian terhadap benda dan/atau keselamatan jiwa seseorang, maka kelalaiam itu dapat dikatakan tindak pidana, ${ }^{1}$ yaitu antara dokter dan pasiennya dalam pelayanan kesehatan.

Sengketa pasien atau keluarganya dan Rumah sakit maupun pekerja rumah sakit (tenaga kesehatan) dalam hal sarana dan fasilitas pelayanan kesehatan disebut sengketa medik. Hal ini akan semakin sulit dan bertele-tele jika sengketa tersebut tersebar dan dimuat dalam berita, sayangnya sering terjadi kesulitan dalam pembuktian fakta hukum karena kurangnya pengetahuan hukum dari aparat, penggunaan pasal yang tidak konsisten serta penggerseran ranah pengadilan.Hasil akhir daripada pelayanaan kesehatan yang tidak sesuai hukum serta kelalaian tenaga kesehatan adalah objek yang sering dipersengketakan. Padahal berdasarkan hukum kesehatan tenaga kesehatan hanya bertanggung jawab atas upaya yang dilakukan (Inspaning Verbinntenis) dan tidak menjamin hasil akhir (Resultalte Verbinntenis). ${ }^{2}$

Kesalahan diagnosis bisa saja terjadi, tidak dapat dipungkiri bahwa dokter juga manusia yang melakukan kesalahan, namun kesalahan, kekeliruan apalagi kelalaian yang telah diperbuat harus tetap dipertanggungjawabkan oleh dokter. Kesalahan-kesalahan pelaksana pelayan kesehatan yang menyebabkan ketidakpuasan pasien atau keluarga pasien, belakangan ini sering diberitakan di berbagai media masa. Penuntutan yang dilakukan pasien atau keluarga pasien terhadap tenaga kesehatan termasuk dokter, mengakibatkan diterapkannya defensive medicine yang malah merugikan pasien itu sendiri. Lalu, perlu digaris bawahi, bahwa layanan kesehatan yang berakibat terjadi kecacatan bahkan kematian, tidak dapat secara langsung termasuk dalam kategori malpraktik.

\footnotetext{
${ }^{1}$ Dalmy Iskandar, Rumah Sakit, Tenaga Kesehatan dan Pasien, Jakarta: Sinar Grafika, (1998), hlm

2 M. Nasser, Sengketa Medis Dalam Pelayanan Kesehatan, (2011), Ari Yunanto \& Helmi, Hukum Pidana Malpraktik Medik, Yogyakarta: Andi Offset, (2010), hlm. 3.
} 
Penelitian mengenai tanggung jawab hukum dokter mengenai kesalahan diagnosis adalah termasuk dalam jenis penelitian normatif atau jenis penelitian yang menggunakan data sekunder melalui pendekatan konseptual, maksudnya penelitian ini meneliti berbagai teori, asas hukum serta aturan-aturan yang berlaku berkaitan dengan topik yang diangkat didalam penelitian ini.

\section{B. Pembahasan}

\section{Keadaan Fasilitas Pelayanan Kesehatan Tingkat Pertama di Lampung Utara}

Lampung Utara adalah merupakan satu dari $15 \mathrm{Kab} / \mathrm{Kota}$ yang ada di Provinsi Lampung .Kotabumi adalah ibukota dari Lampung Utara berada sekitar $\pm 110 \mathrm{~km}$ dari Bandarlampung. Secara administrasi, luas wilayah Lampung Utara adalah 2. 725,35 $\mathrm{Km}^{2}$ terdiri dari 23 Kecamatan dan 247 Kelurahan. Letak geografis Kabupaten Lampung Utara berada di arah Utara-Selatan 434.5.06, LS, 104.40'-LT dan 105' 08' BT, dengan luas areal daratan seluas $272.563 \mathrm{Ha}(7,72 \%)$ dari luas wilayah Provinsi Lampung). Data-Data yang ditemukan mengenai fasilitas pelayanan kesehatan di Lampung Utara, ialah sebagai berikut:.

a. Fasilitas Pelayanan Kesehatan

1) Fasilitas Kesehatan Dasar.

2) Fasilitas Kesehatan Lainnya

3) Fasilitas Kesehatan Bersumber Daya Masyarakat.

b. Kuantitas Tenaga Kesehatan

Jumlah dokter dan perawat di Lampung Utara dalam 2016 tercatat ada 1.475 orang terbagi dalam 12 jenis ketenagaan. Menurut data yang didapat, jumlah tenaga kesehatan yang bekerja di Puskesmas sejumlah 971 dan tenaga kesehatan yang bekerja di rumah sakit sejumlah 504 tenaga kesehatan. Rasio tenaga kesehatan masih jauh dari target nasional, tercatat untuk per 100.ribu penduduk yang mendiami Lampung Utara dalam 2016. Sedangkan rasio jumlah dokter (umum, spesialis, gigi) per100 ribu penduduk yang mendiami Lampung utara dalam 5 tahun belakangan ini terbukti tidak mencapai target. Fakta dan data-data ini membuktikan bahwa perlu ada tanggapan lebih Pemda Lampung Utara dalam rangka penambahan tenaga kesehatan untuk meningkatkan pelayanan kesehatan kepada masyarakat.

\section{Tanggung Jawab Dokter Serta Indikator yang Menyebabkan Tejadinya Kesalahan Diagonosis}

\section{a. Definisi Diagnosis}

Diagnosis merupakan prosedur yang dilakukan dokter untuk menentukan suatu kondisi pasiennya. ${ }^{3}$ Diagnosis juga diartikan sebagai hasil dari evaluasi yang telah dilakukanIndikator diagnosis dilakukan dalam beberapa cara yaitu dengan pemeriksaan fisik, tes laboratorium, atau sejenisnya, serta pemanfaatan teknologi komputer berupa program yang telah dirancang khusus dalam proses penilaian. Penentuan penyakit pasien adalah fungsi utama dari dilakukannya diagnosis terhadap pasien yang melalu beberapa tahapan pemeriksaan, mulai dari anamnesis, pemeriksaan fisik sampai pada pemeriksaan penunjang lainnya. Kewenangan dokter (umum,spesialis maupun dokter gigi) yang terdaftar surat tanda registrasi dalam melakukan tugas sesuai dengan kompetensinya menurut Pasal 35 ayat (1) Undang-Undang No 29 Tahun 2009 tentang Praktek Kedokteran adalah sebagai berikut:

1) Melakukan interview dengan pasiennya mengenai kondisi pasien tersebut

2) Melakukan pemeriksaan fisik mapun mental

3) Menimbang apakah pemeriksaan tambahan dibutuhkan atau tidak

4) Membacakan diagnosa pasien

5) Memutuskan jadwal serta metode pemeriksaan pasien

6) Melakukan tindakan kedokteran atau kedokteran gigi;

\footnotetext{
${ }^{3}$ https://putririnriani.wordpress.com/2014/01/15/pengertian-diagnosis-prognosis-mendengar- danmendengarkan/
} 
7) Menulis resep obat dan alat kesehatan;

8) Menerbitkan surat keterangan dokter atau dokter gigi;

9) Menyimpan obat dalam jumlah dan jenis yang diizinkan;

10) Meracik dan menyerahkan obat kepada pasien, bagi yang praktik di daerah terpencil yang tidak ada apotik.

\section{b. Kesalahan Diagnosis}

Kesalahan diagnosis merupakan kesalahan medis yang terjadi selepas prosedur diagnosis dan pemeriksaan intensif yang di lakukan terhadap pasien oleh seorang dokter. ${ }^{4}$ Sedangkan untuk dikategorikan sebagai malpraktik, kelalaian yang dilakukan seorang dokter dalam melakukan diagnosis harus terlebih dulu di perhatikan apakah dokter tersebut telah menjalankan tugasnya berdasarkan Standar Profesi yang dimiliknya Atau bahkan jika dokter yang bersangkutan terbukti melakukan kesalahan dalam mendiagnosis, tetapi tindakan medik yang dilakukan sesuai dengan peraturan,maka hal tersebut bukanlah termasuk tindakan malpraktek medik/kelalaian medik ${ }^{5}$

Atau bahkan jika dokter yang bersangkutan terbukti melakukan kesalahan dalam mendiagnosis, tetapi tindakan medik yang dilakukan sesuai dengan peraturan,maka hal tersebut bukanlah termasuk tindakan malpraktek medik/kelalaian medik. ${ }^{6}$ Sesuai dengan bahasan diatas, maka ditentukan bahwa dokter harus memperhatikan beberapa aturan-aturan dalam melaksanakan tugasnya, aturan-aturan itu meliputi:

1) Peraturan Perundang-Undangan:

a) Pasal 50 UU NO 29 Tahun 2004 Tentang Praktik Kedokteran:

- Memperoleh perlindungan hukum sepanjang melaksanakan tugas sesuai dengan standar profesi dan standar prosedur operasional.

- Memberikan pelayanan medis menurut standar profesi dan standar prosedur operasional.

b) Pasal 24 ayat 1 UU NO 36 Tahun 2009 Tentang Kesehatan: Tenaga kesehatan sebagaimana dimaksud dalam Pasal 23 harus memenuhi ketentuan kode etik, standar profesi, hak pengguna pelayanan kesehatan, standar pelayanan, dan standar prosedur operasional.

c) Pasal 1 UU No 36 Tahun 2004 Tentang Tenaga Kesehatan Ayat (14): Standar Prosedur Operasional adalah suatu perangkat instruksi/langkah-langkah yang dibakukan untuk menyelesaikan proses kerja rutin tertentu dengan memberikan langkah yang benar dan terbaik berdasarkan konsensus bersama untuk melaksanakan berbagai kegiatan dan fungsi pelayanan yang dibuat oleh Fasilitas Pelayanan Kesehatan berdasarkan Standar Profesi.

2) Kode Etik Kedokteran Indonesia ("KODEKI"):

Pasal 1: Setiap dokter harus menjunjung tinggi, menghayati dan mengamalkan sumpah dokter

Pasal 2: Seorang dokter harus senantiasa berupaya melaksanakan profesinya sesuai dengan standar profesi yang tertinggi

Pasal 6: Setiap dokter harus senantiasa berhati-hati dalam mengumumkan dan menerapkan setiap penemuan teknik atau pengobatan baru yang belum diuji kebenarannya dan hal-hal yang dapat menimbulkan keresahan masyarakat

Pasal 10: Setiap dokter wajib bersikap tulus ikhlas dan mempergunakan segala ilmu dan keterampilan nya untuk kepentingan pasien. Dalam hal ini ia tidak mampu melakukan suatu pemeriksaan atau pengobatan, maka atas persetujuan pasien, ia wajib merujuk pasien kepada dokter yang mempunyai keahlian dalam penyakit tersebut.

Pasal 11: dokter harus memberikan kesempatan kepada pasien agar senantiasa dapat berhubungan dengan keluarga dan penasehatnya dalam beribadat dan atau dalam masalah lainnya.

\footnotetext{
${ }^{4}$ http://kamuskesehatan.com/arti/Salah-diagnosis/.

${ }^{5}$ www.hukumonline.com/klinik/detail/lt5203cbfe5f6aa/langkah-hukum-jika-dokter-salahdiagnosis

${ }^{6}$ www.hukumonline.com/klinik/detail/lt5203cbfe5f6aa/langkah-hukum-jika-dokter-salahdiagnosis
} 


\section{3) Standar Profesi Kedokteran}

Seorang dokter harus melaksanakan kewajibannya sebagai tenaga kesehatan berdasarkan tiga peraturan yang telah disebutkan diatas, dapat disimpulkan bahwa tidak semua kesalahan atas perbuatan medik dokter tersebut dapat diklasifikasikan dalam malpraktek medik. Didefinisikan dalam Kamus Besar Bahasa Indonesia, Standard profesi diartikan sebagai keahlian dasar yang wajib dikuasai oleh pelaku profesi dalam melakukan tugasnya pada masyarakat luas, standar ini dirancang langsung oleh Organisasi keprofesian. Lebih jauh dinyatakan oleh Bapak M.Fakih dalam seminar nasional, bahwa akan di tiadakan sebuah kesalahan atas tindakan kesehatan apabila ada: ${ }^{8}$

a) Risiko dalam pengobatan yaitu resiko yang melekat, risiko akibat reaksi alergik, risiko komplikasi yang timbul dalam tubuh pasien akibat dari pengobatan tersebut.

b) Kesalahan pemeriksaan klinis

c) Terjadi sebuah Kecelakaan Medis

d) Risiko yang telah diketahui sebelumnya oleh Pasien, Resiko ini cenderung besar dan berbahaya

e) Kelalaian yang dibuat sendiri oleh pasien

Dalam menentukan sebuah kesalahan diagnosis akibat dari tindakan dokter merupakan malpraktik medik, dapat dilihat melalui standar yang telah ditentukan, dibawah ini: ${ }^{9}$

1) Harus ditentukan apakah dokter yang bersangkutan memenuhi unsur kelalaian, dalam hal ini dokter dituntut untuk bekerja seteliti mungkin dalam rangka menghindari terjadinya kesalahan diagnosis sebagai akibat dari ketidaktelitiannya, contohnya kesalahan dalam membaca hasil pemeriksaan pasiennya.

2) Tindakan-tindakan dokter dalam melaksanakan tugasnya haruslah sesuai dengan ilmu medis. Hal ini penting sebagai pembuktian tindakan dokter bahwa mereka telah melakukan malpraktik.

3) Keahlian secara rata-rata yang dimiliki tenaga medis dalam kategori yang serupa

4) Terjadi dalam kondisi yang serupa

5) Pengupayaan tindakan medik harus sejalan lurus dengan maksud aktual suatu perbuatan medis tersebut.

Leenen membagi lima kriteria pengujian terhadap tindakan dokter untuk menentukan apakah seorang dokter telah terbukti melakukan kesalahan, kelalaian medik atau malpraktek, yang dikutip pleh Fred Ameln, yaitu: ${ }^{10}$

1) Tindakan dokter yang harus dilakukan secara teliti/saksama (zorgvildig hendelen) dan tidak lalai (culpa). Apabila seoraang dokter terbukti tidak teliti dan tidak berhati-hati, maka ia telah memenuhi unsur kelalaian; dan apabila ia sangat tidak hati-hati, ia memenuhi unsur culpa lata;

2) Tindakan dokter terhadap pasiennya harus serasi dengan ukuran ilmu medik (volgens de medische standard);

3) Kemampuan rata-rata (overage) dibanding kategori keahlian medis yang sama (gemiddelde bewaamheid van gelijke medische categorie);

4) Terjadi dalam kondisi yang serupa (gelijke omstandigheden);

5) Suatu upaya yang proporsional dan memiliki tujuan akhir yang nyata akan tindakan tersebut.

\section{c. Indikator-Indikator Yang Berimbas Pada Terjadinya Kesalahan Diagnosis}

Dokter mempunyai wewenang dalam melakukan praktik sesuai dengan kompetensi dan

\footnotetext{
${ }^{7}$ Ibid

${ }^{8}$ M. Fakih, "Perlindungan Hukum Tenaga Kesehatan Dalam Melakukan Pelayanan Kesehatan di Fasilitas Pelayanan Kesehatan", Seminar Nasional Universitas Gajah Mada, (2017).

9 http://www.hukumonline.com/berita/baca/hol10135/kesalahan-diagnosis-dokter- tergolongmalpraktek-ataukelalaian-medikkah.

${ }^{10}$ Fred Ameln, Kapita Selekta Hukum Kedokteran, Jakarta: Grafikatama Jaya, (1991), hlm. 87.
} 
pendidikan mereka, wewenang ini tercantum dalam surat tanda registrasi berdasarkan Pasal 35

(1) Undang-Undang Praktek Kedokteran. Wewenang yang dimiliki dokter yakni:

1) Melakukan interview dengan pasiennya mengenai kondisi pasien tersebut

2) Melakukan pemeriksaan fisik mapun mental

3) Menimbang apakah pemeriksaan tambahan dibutuhkan atau tidak

4) Membacakan diagnosa pasien

5) Memutuskan jadwal serta metode pemeriksaan pasien

Berdasarkan hal tersebut dapat ditarik kesimpulan bahwa wewenang seoraang dokter atau dokter gigi salah satunya adalah mendiagnosis pasiennya. Terlihat bahwa peran tenaga dokter sangatlah penting, maka kecakapan medik tenaga dokter tentu akan berpengaruh besar terhadap kesuksesan pelaksanaan diagnosis terhadap pasien. Dibawaah ini adalah tahapan-tahapan dalam melakukan diagnosis, yaitu: ${ }^{11}$

1) Anamnesa

Adalah proses wawancara oleh dokter atau tenaga medis yang lain kepada pasien dan atau keluarga pasien dalam rangka menggali informasi tentang penyakit pasien sesuai dengan peraturan yang berlaku

2) Pemeriksaan tubuh/Fisik pasien

Adalah prosedur pelaksanaan pemeriksaan untuk mengetahui kondisi pasien secara konkret

3) Pemeriksaan Penunjang

Pemeriksaan penunjang dilakukan untuk menentukan diagnosis penyakit penderita. Pemeriksaan penunjang ini biasanya dilakukan apabila tindakan- tindakan medis di atas belum dapat memastikan diagnosis suatu penyakit yang diderita pasien sehingga dianggap perlu untuk dilakukan pemeriksaan lebih lanjut.

4) Diagnosis

Diagnosis adalah penetapan jenis penyakit tertentu berdasarkan analisis hasil anamnesis dan pemeriksaan yang cermat. Sumber lain menyatakan bahwa diagnosis juga merupakan pengenalan sifat-sifat penyakit atau kondisi tertentu untuk membedakan satu penyakit dari penyakit yang lain ${ }^{12}$

Indikator lain yang dapat mempengaruhi hasil diagnosis adalah pemeriksaan penunjang. Pemeriksaan ini biasanya dilakukan apabila tindakan-tindakan medis yang disebutkan diatas belum mampu menghasilkan diagnosis suatu penyakit yang diderita pasien, sehingga perlu dilakukan pemeriksaan lebih lanjut atas indikasi tertentu dalam memperoleh keterangan yang lebih menyeluruh. Berdasarkan hal diatas dapat disimpulkan pemeriksaan ini bertujuan untuk:

1) Diagnosa pasien (Diagnostik)

2) Pengobatan tertentu pada pasien sesuai kondisinya (Terapeutik)

3) Pemeriksaan lanjutan (Rontgent, USG dll)

\section{d. Tanggung Jawab Hukum oleh Dokter Atas Kesalahan Diagnosisnya}

Sebelum dijelaskan lebih lanjut mengenai tanggung jawab hukum dokter. Perlu disampaikan secara umum memgenai definisi tanggung jawab itu sendiri. Berdasarkan Kamus Besar Bahasa Indonesia, tanggung jawab diartikan sebagai keharusan dalam melaksanakan sesuatu yang juga berjalan lurus dengan kewajiban menanggung segala perbuatannya tersebut secara penuh. Yang sesuai dengan bahasan penelitian ini, maka tanggung jawab dokter diartikan sebagai keharusan menanggung kesalahan sebagai akibat dari tindakan medis yang dilakukannya (baik sengaja atau tidak).

1) Tanggungjawab dokter dalam bidang hukum perdata

a) Karena Wanprestasi

Pengertian wanprestasi ialah suatu keadaan dimana seseorang tidak memenuhi

11 http://www.medrec07.com/2014/12/pengertian-anamnesa-pemeriksaan-fisik- pemeriksaanpenunjang-diagnosisprognosis-terapi-tindakan-medis.html

12 https://putririnriani.wordpress.com/2014/01/15/pengertian-diagnosis-prognosis-mendengar- danmendengarkan/ 
kewajibannya yang didasarkan pada suatu perjanjian atau kontrak. Pada dasarnya pertanggungjawaban perdata itu bertujuan untuk memperoleh ganti rugi atas kerugian yang diderita oleh pasien akibat adanya wanprestasi atau perbuatan melawan hukum dari tindakan dokter. Menurut ilmu hukum perdata, seseorang dapat dianggap melakukan wanprestasi apabila: Tidak melakukan apa yang disanggupi akan dilakukan, Terlambat dalam melakukan hal yang telah ia janjikan sebelumnya, atau perbuatannya tidak sesuai dengan apa yang sudah diperjanjikan,serta melakukan sesuatu yang menurut perjanjian dianggal sebuah pelanggaran.

b) Tanggungjawab dalam Hukum Perdata akibuat melawan hukum (onrechtmatige daad) Tanggungjawab sebagai akibat dari melawan hukum adalah salah satu bentuk pertanggungjawaban hukum menurut hukum perdata. Berdasarkan KUH Perdata tepatnya pada Pasal 1365 sampai dengan Pasal 1367, Perbuatan Melawan Hukum dibedakan menjadi tiga, yaitu:

- Kesengajaan melakukan perbuatan melawan hukum

- Ketidaksengajaan (tidak ada kesalahan) dalam melakukan perbuatan melawan hukum

- Kelalaian yang menyebabkan terjadinya perbuatan melawan hukum

2) Tanggung jawab dokter dalam bidang hukum pidana

Seiring dengan semakin meningkatnya kesadaran hukum masyarakat, dalam perkembangan selanjutnya timbul permasalahan tanggung jawab pidana seorang dokter, khususnya yang menyangkut dengan kelalaian, hal mana dilandaskan pada teori-teori kesalahan dalam hukum pidana. Tanggung jawab pidana di sini timbul bila pertama-tama dapat dibuktikan adanya kesalahan profesional, misalnya kesalahan dalam diagnosa atau kesalahan dalam cara-cara pengobatan atau perawatan. Suatu perbuatan dapat dikategorikan sebagai criminal malpractice apabila memenuhi rumusan delik pidana yaitu: Perbuatan tersebut harus merupakan perbuatan tercela dan dilakukan sikap batin yang salah yaitu berupa kesengajaan, kecerobohan atau kelapaan. Kesalahan atau kelalaian tenaga kesehatan dapat terjadi di bidang hukum pidana, diatur antara lain dalam: Pasal 263, 267, 294 ayat (2), 299, 304, 322, 344, 347, 348, 349, 351, 359, 360, 361, 531 Kitab Undang-Undang Hukum Pidana.

Ada perbedaan penting antara tindak pidana biasa dengan 'tindak pidana medis'. Pada tindak pidana biasa yang terutama diperhatikan adalah 'akibatnya', sedangkan pada tindak pidana medis adalah 'penyebabnya'. Walaupun berakibat fatal, tetapi jika tidak ada unsur kelalaian atau kesalahan maka dokternya tidak dapat dipersalahkan. Beberapa contoh dari criminal malpractice yang berupa kesengajaan adalah melakukan aborsi tanpa indikasi medis, membocorkan rahasia kedokteran, tidak melakukan pertolongan seseorang yang dalam keadaan emergency, melakukan eutanasia, menerbitkan surat keterangan dokter yang tidak benar, membuat visum et repertum yang tidak benar dan memberikan keterangan yang tidak benar di sidang pengadilan dalam kapasitas sebagai ahli.

3) Tanggungjawab dalam bidang hukum administrasi

Dikatakan pelanggaran administrative malpractice jika dokter melanggar hukum tata usaha negara. Contoh tindakan dokter yang dikategorikan sebagai administrative malpractice adalah menjalankan praktek tanpa ijin, melakukan tindakan medis yang tidak sesuai dengan ijin yang dimiliki, melakukan praktek dengan menggunakan ijin yang sudah daluwarsa dan tidak membuat rekam medis. Pasal 11 Undang-Undang No. 6 Tahun 1963, sanksi administratif dapat dijatuhkan terhadap dokter yang melalaikan kewajiban, melakukan suatu hal yang seharusnya tidak boleh diperbuat oleh seorang dokter, baik mengingat sumpah jabatannya maupun mengingat sumpah sebagai dokter, mengabaikan sesuatu yang seharusnya dilakukan oleh dokter dan melanggar ketentuan menurut atau berdasarkan Undang-Undang No. 6 Tahun 1963.

\section{Ketentuan Hukum Dalam Hal Menuntut Dokter Akibat Kesalahan Diagnosis yang dilakukannya}

\section{a. Tanggung Jawab Etis}


Seorang dokter harus berperilaku sesuai kode etik yang diatur dalam Surat Keputusan Menteri Kesehatan Nomor 434/SK/X Tahun 1983 tentang Kode Etik Kedokteran Indonesia dan Sumpah Dokter Didalamnya telah diatur jenis-jenis pelanggaran etik murni dan pelanggaran etik yang sekaligus melanggar hukum. Maka untuk lebih memperjelas, berikut dipaparkan beberapa contoh pelanggaran etik murni maupun pelanggaran etikolegal (pelanggaran etik disertai pelanggaran hukum), yaitu:

1) Perbuatan Melanggar Etika Murni

a) Meminta Imbalan secara illegal dan berlebihan dari keluarga pasien

b) Mengalihkan pasien tanpa ada izin terlebih dahulu dar keluarga pasien

c) Bersikap arogan/memuji diri secara berlebihan dimuka pasien

d) Pendidikan kedokteran yang dienyam tidak sesuai dengan profesinya sebagai dokter

e) Menyampingkan kesehatan dirinya (dokter) sendiri

2) Perbuatan melanggar etikolegal

a) Dokter Melayani Pasien tidak sesuai standard yang ditentukan

b) Membuat surat keterangan illegal/palsu

c) Aborrtus Provokatus

d) Menyebarkan secara umum dan tidak bertanggung jawab mengenai pekerjaan dokter

\section{b. Tanggungjawab Disiplin}

Tanggung Jawab Disiplin diatur dalam Pasal 69 Ayat (3) Undang-Undang Praktik Kedokteran tanggung jawab disiplin yang dimaksud adalah berupa:

1) Pemberian peringatan tertulis

2) Rekomendasi pencabutan Surat Tanda Registrasi atau Surat Ijin Praktek.

3) Kewajiban mengikuti pendidikan dan pelatihan institusi pendidikan kedokteran atau kedokteran gigi.

\section{c. Tanggung Jawab Pidana}

Tanggung Jawab Pidana seorang dokter diatur dalam Undang-Undang Nomor 29 Tahun 2004 Tentang Praktek Kedokteran, terdapat enam pasal yang menjelaskan mengenai tindak pidana pada bidang kesehatan, antara lain:

1) Tindak pidana praktek kedokteran tanpa Surat Tanda Registrasi (STR) (Pasal 75)

2) Tindak pidana praktek kedokteran tanpa Surat Ijin Praktek (SIP) (Pasal 76)

3) Tindak pidana menggunakan identitas gelar atau bentuk lain yang menimbulkan kesan dokter yang memiliki STR dan SIP (Pasal 77)

4) Tindak pidana menggunakan alat, metode pelayanan kesehatan yang menimbulkan kesan dokter yang memiliki STR dan SIP (Pasal 78)

5) Tindak pidana dokter praktek yang tidak memasang papan nama, tidak membuat rekam medis dan tidak berdasarkan Standar Profesi (Pasal 79) 6) Tindak pidana memperkerjakan dokter tanpa SIP (Pasal 80)

\section{Penutup}

\section{Kesimpulan}

Sesuai dengan pembahasan yang dipaparkan diatas, maka dapat disimpulkan:

a Terdapat beberapa hal yang menjadi indikator terjadinya kesalahan diagnosis, diantaranya kuantitas jumlah tenaga kesehatan yang masih dibawah target, sarana kesehatan tambahan yang sangat kurang, hal ini terbukti dari data yang didapat di Lampung Utara yang memiliki tenaga kesehatan yang belum sesuai target sesuai peraturan yang belaku, bahkan ada beberapa tempat pelayanan kesehatan tidak memiliki dokter sama sekali. Ketersediaan 
sarana pemeriksaan tambahan pun belum memadai, seperti kurangnya fasilitas Rontgent, USG dan lain sebagainya.

b. Dalam melakukan tugasnya, dokter tidak luput dari kesalahan, contohnya kesalahan diagnosis. Jika hal ini terjadi maka dokter dapat dituntut dengan dasar hukum dari Peraturan Perundang-undangan yang berlaku, standard profesi, SOP maupun KODEKI.

\section{Saran}

Terdapat saran-saran yang didapat setelah pemaparan diatas yang sejalan dengan pokok bahasan, yaitu:

a Seperti yang tertera pada data, Pemerintah Kabupaten Lampung Utara harus memberikan perhatian khusus dalam rangka penambahan jumlah Tenaga Kesehatan (dokter) serta melengkapi fasilitas guna pemeriksaan penunjang dalam meminimalisir terjadinya kesalahan diagnosis pasien

b. Berdasarkan penjelasan dalam penelitian ini mengenai peraturan perundang- undangan, seorang dokter dituntut untuk melaksanakan tugasnya termasuk dalam hal mendiagnosis pasian harus sesuai dengan kode etik kedokteran, standar profesi dan standar prosedur operasional.

\section{A. Buku}

\section{Daftar Pustaka}

Ari Yunanto \& Helmi. (2010). Hukum Pidana Malpraktik Medik. Yogyakarta: Andi Offset. Dalmy, Iskandar. (1998). Rumah Sakit, Tenaga Kesehatan dan Pasien, Jakarta: Sinar Grafika, Iskandar, Dalmy. (1998). Rumah Sakit, Tenaga Kesehatan dan Pasien. Jakarta: Sinar Grafika. M. Nasser SpKK.D.Law. (2011). Sengketa Medis Dalam Pelayanan Kesehatan.

Soemitro, Ronny Hanitijo. (1985). Metodologi Penelitian Hukum. Jakarta: Balai Aksara.

\section{B. Peraturan Hukum}

Undang- Undang Nomor 36 Tahun 2004 Tentang Tenaga Kesehatan Kode Etik Kedokteran Indonesia ("KODEKI")

Undang-Undang Nomor 29 Tahun 2009 tentang Praktek Kedokteran

Undang-Undang Nomor 36 Tahun 2009 Tentang Kesehatan

\section{Internet dan Makalah}

http://kamuskesehatan.com/arti/Salah-diagnosis/.

http://www.medrec07.com/2014/12/pengertian-anamnesa-pemeriksaan- fisikpemeriksaanpenunjang-diagnosis-prognosis-terapi-tindakan- medis.html

https://putririnriani.wordpress.com/2014/01/15/pengertian-diagnosis- prognosismendengar-danmendengarkan/

M. Fakih, "Perlindungan Hukum Tenaga Kesehatan Dalam Melakukan Pelayanan Kesehatan di Fasilitas Pelayanan Kesehatan", Seminar Nasional Universitas Gadjah Mada, 2017. 
